\title{
Archaeological Survey of a Proposed Riverside Park Trail at the Victoria Municipal Park, Victoria, Texas
}

Anna J. Taylor

Follow this and additional works at: https://scholarworks.sfasu.edu/ita

Part of the American Material Culture Commons, Archaeological Anthropology Commons, Environmental Studies Commons, Other American Studies Commons, Other Arts and Humanities Commons, Other History of Art, Architecture, and Archaeology Commons, and the United States History Commons

Tell us how this article helped you.

This Article is brought to you for free and open access by the Center for Regional Heritage Research at SFA ScholarWorks. It has been accepted for inclusion in Index of Texas Archaeology: Open Access Gray Literature from the Lone Star State by an authorized editor of SFA ScholarWorks. For more information, please contact cdsscholarworks@sfasu.edu. 


\section{Archaeological Survey of a Proposed Riverside Park Trail at the Victoria Municipal Park, Victoria, Texas \\ Creative Commons License \\ (c) (1) (8)}

This work is licensed under a Creative Commons Attribution-NonCommercial 4.0 International License 
ARCHAEOLOGICAL SURVEY OF A PROPOSED RIVERSIDE PARK TRAIL

AT THE VICTORIA MUNICIPAL PARK, VICTORIA, TEXAS

Anna J. Taylor

Texas Antiquities Committee Permit No. 481

Dr. Thomas R. Hester, Principal Investigator

Center for Archaeological Research The University of Texas at San Antonio ${ }^{\circledR}$

Archaeological Survey Report, No. 155 
The following information is provided in accordance with General Rules of Practice and Procedure, Chapter 41.11 (Investigation Reports), Texas Antiquities Committee:

1. Type of Investigation: Archaeological Pedestrian Survey of a proposed Riverside Park trai1:

2. Project Name: Victoria-Riverside Park Trail;

3. County: Victoria County, Texas;

4. Principal Investigator(s): Dr. Thomas R. Hester, Principal Investigator, and Jack D. Eaton, Co-Principal Investigator;

5. Name and Location of Sponsoring Agency: City of Victoria, Texas;

6. Texas Antiquities Committee Permit No. 481;

7. Published by the Center for Archaeological Research, The University of Texas at San Antonio, San Antonio, Texas 78285, 1985.

A 1 ist of publications offered by the Center for Archaeological Research can be obtained by sending $\$ 1.00$ to the Center for Archaeological Research, The University of Texas at San Antonio, San Antonio, Texas 78285. 
TABLE OF CONTENTS

LIST OF FIGURES ...................... . . .

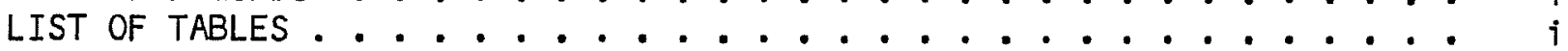

ABSTRACT ............................. $i$

ACKNOWLEDGMENTS .......................... $i \uparrow$

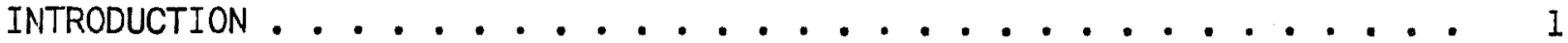

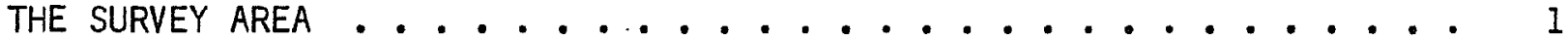

Environmental Background ............... 3

Archaeological Background .............. . . 4

Culture History ................. . . 4 4

Previous Archaeological Investigations . . . . . . . . 5

SURVEY METHODS AND RESULTS ................... 6

SUMMARY AND RECOMMENDATIONS ............... 6

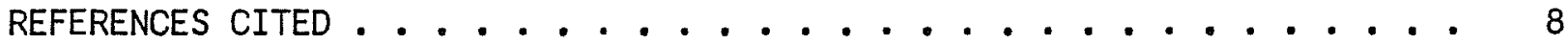

\section{LIST OF FIGURES}

1. Location of the Proposed Riverside Park Trail Survey Area in

Victoria County, Texas ...............

LIST OF TABLES

1. Shovel Test Results ................... 


\begin{abstract}
During April 1985, personnel from the Center for Archaeological Research, The University of Texas at San Antonio, conducted a pedestrian survey and shovel testing of the area to be affected by a proposed riverside park trail within the Victoria Municipal Park in Victoria County, Texas. The investigation was sponsored by the City of Victoria. The purpose of the survey was to locate any archaeological sites which might be impacted by construction of the proposed trail. No archaeological sites were identified during the project, and it is recommended that no further archaeological investigations are needed.
\end{abstract}


Many people helped to make this project possible. We are grateful to Jack Murphy, Director of the Parks and Recreation Department for the City of $V$ ictoria, for his assistance with the project. Paul Locher, Superintendent of the Parks and Recreation Department for the City of Victoria, assisted with the survey and provided information concerning the background of the survey area. Lucy Swanger, librarian at the Victoria Public Library Donor Room, located numerous references on the history of $V$ ictoria County for the author. Sonny Timme and Bill Birmingham, local amateur archaeologists, discussed the prehistoric and historic archaeological resources of the Victoria area with the author.

The field survey was accomplished by CAR-UTSA personnel A. J. Tay Tor, Research Associate, with the volunteer assistance of Paul Locher of Victoria. Anne Fox and Ken Brown, Research Associates of the CAR-UTSA, provided historical and archaeological information concerning $V$ ictoria County. The project was supervised by Dr. Thomas R. Hester, principal investigator and Director of the CAR-UTSA, and by Jack D. Eaton, co-principal investigator and Associate Director of the CAR-UTSA. The CAR-UTSA office staff, particularly Sharon Quirk, editor, aided in the preparation of this report. 



\section{INTRODUCTION}

In February 1985, the Center for Archaeological Research, The University of Texas at San Antonio (CAR-UTSA), was requested by Paul Locher, Superintendent of the Parks and Recreation Department for the City of Victoria, Texas, to conduct a pedestrian survey along the proposed route for a nature trail in the Victoria Municipal Park (Fig. 1). The project was undertaken to enable the $C i t y$ of $V$ ictoria to construct the nature trail within the survey area. The Texas Parks and Wildlife Department, the Texas Historical Commission, and the Texas Antiquities Committee, recommended that an archaeological survey be conducted of the area planned for the nature trait since the survey area is 1 ocated roughly $200 \mathrm{~m}$ downslope from an archaeological site (4I VT 10) which is on the National Register of Historic Places, and also because the survey area appeared to be in a high probability area for prehistoric sites. The survey was directed toward identifying any National Register-eligible sites so that proper measures could be taken prior to any construction activities. The survey was done in compliance with the National Historic Preservation Act of 1966 (as amended) and its implementing regulations, 36CFR800; the National Environmental Policy Act of 1969; and Executive Order 11593. The survey was carried out under Texas Antiquities Committee Permit No. 481.

The survey, designated as the Victoria-Riverside Park Trail project, was conducted by A. J. Taylor, Research Associate at the CAR-UTSA, with the assistance of Paul Locher, Superintendent of the Parks and Recreation Department for the City of Victoria, on Apri1 22, 1985. The project also included examining 1 and deed records in the Victoria County Courthouse and reviewing $10 c a 1$ historical resources in the Victoria Public Library. Project supervision was provided by the principal investigator, Dr. Thomas R. Hester, Director of the CAR-UTSA, and co-principal investigator, Jack D. Eaton, Associate Director of the CAR-UTSA.

\section{THE SURVEY AREA}

The survey area for the proposed nature trail extends for rough 1 y $914.4 \mathrm{~m}$ (3000 feet) on the northern border of the Victoria Municipal Park. The area is from $10 \mathrm{~m}$ to $15 \mathrm{~m}$ wide, and is located between a paved road, McCright Drive, and the Guadalupe River.

The survey area is 1 ocated within farm 1 ots 1,2 , and 3 in b 1 ock 3 , range 1. This property was originally included within the Martin de Leon colony which was granted in 1824 to Empresario (a 1 and agent or 1 and contractor for the colonization system used by the Mexican government) Martin de Leon (Webb 1952 Vol. 1:484, 566). The survey area was part of a 1 eague of 1 and granted to Jose Maria Hernandez on May 1, 1835, by Fernando de Leon who was commissioned on March 10, 1832, by the State of Coahuil a and Texas to distribute vacant 1 and to the colonists introduced by his father. The property was 1 ater received as a headright (a 1 and grant made to settlers by the Republic of Texas under the Constitution of 1836; Webb $1952 \mathrm{Vol}$. 2:20) in 1839, by James Kerr, who had surveyed the property for Hernandez, the previous 1 andowner (Deed Index V01. 1:188, Apri1 18, 1839). The property was transferred to Alexander H. Phillips on August 13, 1841, and Phillips retained it until 1877 (Deed Index Vo1. 15:494-495, August 22, 1877); the property was included 
This page has been

redacted because it

contains restricted

information. 
within the town of Guadalupe Victoria at that time. In the succeeding records of transactions of the property, mention is made that the property was common 1 y known as the Phi 11 ips 1 abor (see Deed Index Vo 1. 15:494-495, August 22, 1877; Vo1. 38:339-340, August 6, 1897), presumably named after

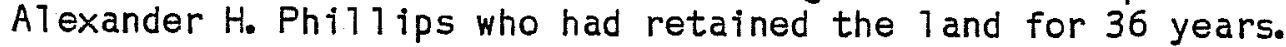

During recent times, before the establishment of the Victoria Municipal Park, the area was used for gravel and sand mining, and various roads covered with gravel or pavement once extended through the survey area ( $P$ aul Locher, personal communication). The location of one such road could be discerned during the survey by its sunken, 1 inear appearance.

\section{ENV IRONMENTAL BACKGROUND}

The general survey area is located in the Gulf Coast Plain in the vicinity of the transition zone between the Oak-Hickory Forest zone and the Coastal Prairie. The area is also in a transition zone between the Tamaulipan Biotic Province to the southwest which is characterized by thorny brush and cacti, and the Texan Biotic Province to the northeast which is characterized by deciduous forests (Arbingast et a1. 1973; B1air 1950). Vegetation within the park includes 1 ive oak, anaqua, huisache, mesquite trees, mustang grape, and open grassy areas which appear to have resulted from clearing of the locality for the park and a nearby golf course.

Mammals which are found in the study area include opossum, various types of bats, various types of mice, the Plains pocket gopher, armadil10, cottontail rabbit, fox squirre1, and whitetail deer. There is a 1 arge variety of $10 \mathrm{ca} 1$ and migrating birds. Numerous types of reptiles and fish also occupy areas along the tributaries.

The general area is a gently rolling coastal prairie with an average altitude of $30.48 \mathrm{~m}$ (100 feet) above mean sea level (ms1). The elevation of the survey area ranges from $18.29 \mathrm{~m}$ (60 feet) to $24.36 \mathrm{~m}$ (70 feet) above mean sea 1eve1. The nature trail will extend along a terrace which borders the Guadalupe River.

The survey area is located within a wide belt of alluvium along the floodplain of the Guadalupe River, which consists of Recent clay, silt, sand, and. grave1. There are some older deposits exposed in pits with in the floodplain, however, in the vicinity of Victoria. The Tonkawa Bluff site (4I VT 10) is located outside of the alluvial deposits, and has Pleistocene soils of the Beaumont formation which include barrier island and beach deposits. There are some gravel deposits in the Beaumont formation, mainly along the Guadalupe River near Victoria (Bureau of Economic Geology 1975).

The climate is humid and subtropical with hot summers and cool winters. The weather is influenced by polar air masses which create 1 arge temperature fluctuations. Two rainy seasons occur, one in the late spring to early summer and the other during the autumn. Occasionally severe thunderstorms cause flooding on the local creeks and rivers, and periodically high winds and extreme flooding caused by hurricanes also occur. The annual rainfall in Victoria averages $90.58 \mathrm{~cm}$ (35.66 inches; Webb 1952 Vol. 2:840). 
ARCHAEOLOGICAL BACKGROUND

\section{Culture History}

Man has been present in North America back to at least 9000 B.C., during the end of the Pleistocene, or Ice Age, in what is known as the Paleo-Indian period (9200-8000 B.C.). During this period peoples hunted big game animals, but al so gathered a wide range of food resources. The fol 1 owing period, known as the Archaic (ca. 8000 B.C. -1000 A.D.), begins with the development of modern climatic conditions. The term Archaic broadly refers to hunting and gathering, preagricultural Indian groups. Sometime after A.D. 1000 in south Texas, new technology which included the bow and arrow, rather than the previously used atlat l, new stone tools, and also plain pottery known as Leon Plain, was introduced to the hunting and gathering groups. The first Historic contacts in south Texas, during the 1520s-1530s, were brief and had little impact upon the aboriginal occupants of the region. It was not until Spanish missions were built in south Texas during the late 1600 s and early 1700 s that the Indians were much affected. Archaeological sites in the $V$ ictoria area contain evidence of man's presence from the Paleo-Indian period, through the Late Prehistoric period, to the early European contact and more recent times (Fox and Hester 1976; Hester 1980:28-31, 131-164).

Groups of Indians 1 iving on the bays and rivers in the Victoria area were reported by the first Europeans who were in the vicinity in the 1600s. These Indians appear to have been the Aranama, a Coahuilteco-speaking band who 1 ived primarily on the Guadalupe River near present-day Mission Valley; and the Karankawa who occupied the coastal bays and islands, but sometimes moved farther inland for brief periods. Additionally, a group of Tonkawa, a central Texas group, appear to have migrated into the area in the 1700s (Linn $1883: 334$ ).

The first European influence in the immediate area occurred in 1726 when the Spanish Mission Nuestra Señora del Espiritu Santo de Zuñiga and the Presidio Nuestra Señora de Loreto were moved to a location along the Guadalupe River, north of the present-day town of Victoria. The Spanish influence was short1 ived, however, as the mission and the fort were moved to the present site of Gol iad in 1749 (Castañeda 1936:79-113, 168-169).

European occupation of the Victoria area began in 1824, with the arrival of Empresario Don Martin de Leon. It was not unti 1 1833-1835, however, that most of the grants for the colonists were formally certified. Each colonist who was the head of a household and intended to raise 1 ivestock was entitled to one 1 eague (4428 acres) of grazing 1 and in addition to one 1 abor (177 acres) of arable 1 and for planting crops, and a building lot for his home inside the town. The town of Victoria was founded in 1832, and 41 families settled on the 1 ands surrounding the town (Rose 1883:10). Weisiger (1969 citing Linn 1883) mentions that a ford known as the "El Paso del Gobernors" was located below the hill on which the Tonkawa Bluff site (4I VT 10) is located, and it was part of the Atascosito Road which was established in 1757 as a military road which 1 ed from Refugio and Goliad to Atascosito Spring near Liberty, Texas. 
The Texas Revolution in 1835-1836 did not directly involve the immediate survey area, though the battle which resulted in the capture of Fannin (sometimes called the Battle of Coleto Creek) occurred six or seven miles southwest of the intersection of the Victoria Road with Coleto Creek. The main effect of the Texas Revolution upon the general area was the flight of the Mexican population to Mexico and their subsequent replacement by AngloAmericans who moved in and took possession of their 1 ands (O'Connor $1966: 243)$. This probably accounts for changes in property owners during this general time.

Victoria was a main stop on the cart road and immigrant route from Indianola to San Antonio and the new German settlements at New Braunfels and beyond. The function of the town as a major stop resulted in numerous immigrants settling in the town rather. than traveling further inland (Fox and Livingston 1979:2, 4). Many settlers from the 0ld South moved to the area and established plantations and ranches. The Gulf, West Texas, and Pacific Rail road was completed from Port Lavaca to Victoria in 1860. The railroad tracks were destroyed by Federal troops during the Civil War, however, and it was not until 1869 that the 1 ine was back in operation and was continued to Indianola. Agriculture and ranching were the primary occupations in the area until the 1 ate 1930 s when 011 was discovered, resulting in a marked increase in the population (Webb 1952 Vol. 2:840).

\section{Previous Archaeological Investigations}

The Tonkawa Bluff site (4I VT 10), roughly $200 \mathrm{~m}$ northeast of the proposed survey area, was dug and reported by an amateur archaeologist, John Littlefield Jarratt of Victoria, during 1931 and 1932; the site area was also local1y known as Hiller's Mott (named after Adam J. "Doc" Hiller, the 1 andowner), Jarratt reported finding prehistoric materials and historic Spanish materials and also human burials during his excavations (Jarratt 1932, 1966a, 1966b, 1966c; Morris 1953; Weisiger 1969:3). The site was then tested by students directed by Arthur M. Woolsey from The University of Texas at Austin during June 27-29, 1932; at that time the site was referred to as the Doc Hiller Farm site. Though the 1 andowner had reported that several human skeletons had been recovered from the site, Woolsey's excavations failed to recovered more than a 1 imited amount of flint artifacts (Morris 1953; Wool sey 1932). In 1979, preliminary testing of the Tonkawa Bluff site was conducted. by Anne A. Fox of the CAR-UTSA to determine the site 1 imits. Fox (1979) reported that the Tonkawa Bluff site was found to have both prehistoric and historic occupation components. The prehistoric component of the site appears to date from the Early Archaic period (ca. 5000 B.C.). The historic component includes the remains of Spanish Colonial structures and materials, including burials, dating to the first half of the 18 th century. Fox (1979:6) concluded that the site may have once been an intermediate location of the Presidio La Bahia, or the associated Mission Espiritu Santo, dating from 1722 to 1726, or perhaps it was a mission outpost or a mission ranch headquarters which was converted into a mission for the Tonkawa Indians. 


\section{SURVEY METHODS AND RESULTS}

The Victoria-Riverside Park Trail survey was a $100 \%$ pedestrian survey of the project area done in a single transect by two persons. The project included surveying, digging shovel tests, recording survey data, record research, and al so preparation of a technical report describing the project. Black and white $35 \mathrm{~mm}$ photographs, a photograph 10g, and al1 records are curated at the CAR-UTSA 1 aboratory.

The two surveyors walked the trail route searching for evidence of cultural materials or features, none of which were found. Eight shovel tests were dug at intervals along the proposed trail route to examine the subsurface deposits. The results of the shovel tests are described in Table 1. Only modern features, paved and graveled roads, were found in the shovel tests; no other cultural features or materials were observed. A depth of $40 \mathrm{~cm}$ bel ow modern ground surface for the shovel tests was considered sufficient to test for cultural features to be impacted by construction of the nature trail since the trail is not planned to exceed $10 \mathrm{~cm}$ to $15 \mathrm{~cm}$ in depth (Paul Locher, personal communication).

The scarcity of cultural remains on the surface of the survey area may be due to natural and man-made factors. This area, which is located immediately along the Guadalupe River, is subject to periodic flooding which would result in the deposition of appreciable amounts of water-borne sediments over any existing cultural remains. The area is also in the vicinity of gravel quarrying operations, according to Paul Locher (personal communication), which may have removed any cultural remains.

The results of the archaeological survey of the proposed Riverside Park Trail area are as follows. With the exception of modern gravel and paved roads, no cultural materials or features were observed within the survey area. Though the trail will be located in an area with high topographic potential for prehistoric archaeological sites, no evidence of such sites was observed. The Tonkawa Bluff site (4IVT 10), an archaeological site 1 isted on the National Register of Historic Places, will not be affected by the proposed park trail.

\section{SUMMARY AND RECOMMENDATIONS}

Based upon the 1 ack of evidence indicating the presence of surface or subsurface archaeological materials or remains within the survey area, it is recommended that no further archaeological investigations are necessary. 


\section{TABLE 1. SHOVEL TEST RESULTS}

Shovel

Test No. Depth Description

\begin{tabular}{|c|c|c|}
\hline 1 & $40 \mathrm{~cm}$ & $\begin{array}{l}\text { Dark gray sandy clay mottled with tan sand and a few small } \\
\text { gravels. The soil had a uniform appearance with no } \\
\text { discernible stratigraphy and appeared to be alluvium } \\
\text { resulting from repeated flooding of the nearby Guadalupe } \\
\text { River. }\end{array}$ \\
\hline 2 & $40 \mathrm{~cm}$ & $\begin{array}{l}\text { Tan silty loamy clay with dark gray mottling and a few } \\
\text { small gravels. The soil had a uniform appearance with no } \\
\text { discernible stratigraphy and appeared to be alluvium } \\
\text { resulting from repeated flooding of the nearby Guadalupe } \\
\text { River. }\end{array}$ \\
\hline 3 & $20 \mathrm{~cm}$ & $\begin{array}{l}\text { Medium gray silty loam mottled with tan clay and a few } \\
\text { small gravels. The soll had a uniform appearance and may } \\
\text { be alluvium resulting from repeated flooding of the nearby } \\
\text { Guadalupe River. Excavations were discontinued when an } \\
\text { asphalt and gravel road surface was encountered at } 20 \mathrm{~cm} \\
\text { below the modern ground surface. }\end{array}$ \\
\hline
\end{tabular}

$4 \quad 40 \mathrm{~cm}$

Gray tan fine clayey loam with a few small gravels. The soll had a uniform appearance with no discernible stratigraphy and appeared to be alluvium resulting from repeated flooding of the nearby Guadalupe River.

$5 \quad 40 \mathrm{~cm}$

Gray tan sflty loamy clay. Small pieces of gold and pink sandstone and al so possibly concrete (from a former gravel roadbed?) were encountered at $25 \mathrm{~cm}$ below the modern ground surface. The soll had a uniform appearance with no discernible stratigraphy and appeared to be alluvium resulting from repeated flooding of the nearby Guadalupe River.

$6 \quad 40 \mathrm{~cm}$

Gray tan silty clay. loam with a small amount of tan mottling of the same consistency. A few small 1 and snails were observed from $0-10 \mathrm{~cm}$ below the modern ground surface. No gravels were observed. The soit had a uniform appearance with no discernible stratigraphy and appeared to be alluvium resulting from repeated flooding of the nearby Guadalupe River.

$7 \quad 40 \mathrm{~cm}$

Gray silty clay loam. No mottling or gravels were observed, but a few 1 and snails were in the upper levels of the sol1. At $8 \mathrm{~cm}$ below the modern ground surface, an asphalt and gravel roadbed was encountered. The soll had a uniform appearance above and below the roadbed, with no discernfble stratigraphy and appeared to be al1uvium resulting from repeated flooding of the nearby Guadalupe River.

$8 \quad 40 \mathrm{~cm}$

Dark gray silty loam clay was present from $0-20 \mathrm{~cm}$ below the modern ground surface. At $20 \mathrm{~cm}$ a gravel roadbed was encountered. Beneath the roadbed, from $25-40 \mathrm{~cm}$ below the modern ground surface, was a silty clay loam with no gravels. Both kinds of solls, those above and below the roadbed, had a uniform appearance with no discernible stratigraphy and appeared to be al luvium resulting from repeated flooding of the nearby Guadalupe River. 
Arbingast, S. A., L. G. Hennamer, R. H. Ryan, A. Lo, D. L. Karney, C. P. Zlatovich, M. E. Bonine, and R. G. Steele

1973 Atlas of Texas. Bureau of Business Research. The University of Texas at Austin.

Blair, W. F.

1950 The Biotic Provinces of Texas. The Texas Journal of Science 1(2):93-116.

Bureau of Economic Geology

1975 Geologic Atl as of Texas. Beeville-Bay City Sheet. Alexander Deussen Memorial Edition. The University of Texas at Austin.

Castañeda, C. E.

1936 The Mission Era: The Winning of Texas, 1693-1731. Our Cathol ic Heritage in Texas 2. Von Boeckmann-Jones, Austin.

Fox, A. A.

1979 Preliminary Report of Archaeological Testing at the Tonkawa Bluff, Victoria City Park, Victoria, Texas. Center for Archaeological Research, The University of Texas at San Antonio, Archạeological Survey Report 70.

Fox, A. A. and T. R. Hester

1976 An Archaeological Survey of Coleto Creek, Victoria and Goliad Counties, Texas. Center for Archaeological Research. The University of Texas at San Antonio. Archaeological Survey Report 18.

Fox, A. A. and K. Livingston

1979 Historical, Architectural and Archaeological Investigations at the Steiner-Schob Complex, Victoria County, Texas. Center for Archaeological Research. The University of Texas at San Antonio, Archaeological Survey Report 52.

Hester, T. R.

1980 Digging Into South Texas Prehistory: A Guide for Amateur Archaeologists. Corona Publishing Company, San Antonio, Texas. 
Jarratt, J. L., Sr.

1932 Toncahua Indian Village. Unpublished manuscript on file at the Victoria Junior Coll lege Library Archives, Victoria, Texas.

1966a Field Notes, and Narrative on $01 d$ Spanish Ruins, at the Toncahua Indian Village, on the Toncahua Bank on the Guadalupe River, North End of the City Park, Victoria, Victoria County, Texas, 1965-1966. May 1, 1966. Unpub 1 ished manuscript on file at the Victoria Junior College Library Archives, victoria, Texas.

1966b The Complex of Spanish Forts and Missions on the Guadalupe River, 1726-1749. Paper presented at the Texas Archeological Society Meeting, November 12, 1966. Unpub 1 ished manuscript on file at the Victoria Junior College Library Archives, Victoria, Texas.

1966c Toncahua Village Excavations and Excavations around $01 d$ Spanish Fort, Field Notes, 1965-1966. Unpublished manuscript on file at the Victoria Junior College Library Archives, victoria, Texas.

Linn, J.

1883 Reminiscences of Fifty Years in Texas. D. and J. Sad1er, New York.

Morris, L.

1953 Pictorial History of Victoria and Victoria County. Clemens Printing Co., San Antonio, Texas.

O'Connor, K. S.

1966 The Presidio La Bahia del Espiritu Santo de Zuñiga, 1721-1846. Von Boeckmann-Jones, Austin.

Rose, V. M.

1883 Some Historical Facts in Regard to the Settlement of Victoria, Texas. Daily Times Print.

Victoria County, Texas

Deed Index. Victoria County Courthouse, Victoria County, Texas.

Webb, W. P., editor-in-chief

1952 The Handbook of Texas. Two volumes. The Texas State Historical Association, Austin. 
Weisiger, S. R.

1969 Riverside or Tonkawa Park. The Victoria Advocate December $28: 3$.

Woolsey, A. M.

1932 Excavation of Site on Dock Hiller Farm [4I VT 10]. Manuscript on file at the Texas Archeological Research Laboratory, The University of Texas at Austin. 